\title{
Use of geostatistics on broiler production for evaluation of different minimum ventilation systems during brooding phase
}

\author{
Thayla Morandi Ridolfi de Carvalho ${ }^{1}$, Daniella Jorge de Moura ${ }^{1}$, Zigomar Menezes de Souza ${ }^{2}$, \\ Gustavo Soares de Souza ${ }^{2}$, Leda Gobbo de Freitas Bueno ${ }^{1}$, Karla Andrea Oliveira de Lima ${ }^{1}$ \\ ${ }^{1}$ Departamento de Construções Rurais e Ambiência - FEAGRI/UNICAMP, Cidade Universitária, Campinas, SP, Brazil. \\ 2 Departamento de Água e Solo - FEAGRI/UNICAMP, Cidade Universitária, Campinas, SP, Brazil.
}

\begin{abstract}
The objective of this research was to evaluate different minimum ventilation systems, in relation to air quality and thermal comfort using geostatistics in brooding phase. The minimum ventilation systems were: Blue House I: exhaust fans + curtain management (end of the building); Blue House II: exhaust fans + side curtain management; and Dark House: exhaust fans + flag. The climate variables evaluated were: dry bulb temperature, relative humidity, air velocity, carbon dioxide and ammonia concentration, during winter time, at 9 a.m., in 80 equidistant points in brooding area. Data were evaluated by geostatistic technique. The results indicate that Wider broiler houses (above $15.0 \mathrm{~m}$ width) present the greatest ammonia and humidity concentration. Blue House II present the best results in relation to air quality. However, none of the studied broiler houses present an ideal thermal comfort.
\end{abstract}

Key Words: air quality, environment, kriging, poultry, welfare

\section{Introduction}

Minimum ventilation is defined as the air flow necessary to provide oxygen renewal, keeping the air quality and improving animal welfare. Air renewal should keep the ambient temperature at appropriate levels to birds during initial growing phase, besides removing the excessive humidity from the environment, maintaining the litter quality and reducing the gas concentration (Cordeiro et al., 2010).

The maximum ammonia concentration levels for birds must be about $20 \mathrm{ppm}$, while for carbon dioxide, about 5,000 ppm. Metabolic syndromes and respiratory diseases are related to low oxygen concentration in the brooding area due to improper air exchanges (Maxwell \& Robertson 1998). High gas concentration in broiler houses has been reported by several researchers (Redwine et al., 2002; Miles et al., 2004; Miles et al., 2006; Miles et al., 2008).

The ideal air velocity must be lower than $2 \mathrm{~m} / \mathrm{s}^{-1}$ for birds during brooding phase. However, the efficiency of ventilation system must be taken into account on exhaust fans performance in tunnel ventilated houses (Simmons et al., 2003).

Geostatistics is a statistical tool used to analyze datasets based on the random function (random variable) by spatial dependence analysis. Spatial dependence must be estimated by geostatistical technique, through semivariance data analysis (Vieira, 2000). Faria et al. (2008) determined the spatial variability and homogeneity of microclimate in environment for dairy cattle through different climatization systems evaluation. Miles et al. (2008) assessed the spatiotemporal variability for $\mathrm{NH}_{3}$ and $\mathrm{N}_{2} \mathrm{O}$ flow from broiler litter.

The knowledge of spatial variability of thermal and aerial environment of broiler houses during the brooding phase is important for a better management of poultry production. Variables like temperature, relative humidity, air velocity, $\mathrm{NH}_{3}$ and $\mathrm{CO}_{2}$ influence behavior, welfare and performance of confined animals. Therefore, the assessment of these variables distribution as well as the kriging technique may contribute to the proper management of animal production. According to this assumption, the research was carried out aiming to assess the influence of different minimum ventilation schemes on the thermal and aerial environment of broiler houses during brooding phase using the geostatistical analysis.

\section{Material and Methods}

This research was carried out in two commercial broiler houses during the winter in 2008. Aviaries were named Blue House I and Blue House II, located in the municipality of Monte Alegre do Sul, in São Paulo state, Brazil. The average altitude of this region is $750 \mathrm{~m}$ and Cwa climate presenting two seasons described according to Köppen climate classification. Aviaries designs were $22.0 \times 90.0 \times 3.00 \mathrm{~m}$ and 
$9.0 \times 125.0 \times 3.25 \mathrm{~m}$ for Blue House I and Blue House II, respectively. Both buildings had east-west orientation and the minimum ventilation system was provided by running exhaust fans and sidewall curtain openings, according to curtains management (Figures 1A and 1B).

Houses were split in small areas used for heating phase named brooding chamber. Dimensions varied according to the week of grow-out cycle. Blue House I had dimensions $22.0 \times 30.0 \mathrm{~m}, 22.0 \times 60.0 \mathrm{~m}$ and $22.0 \times 90.0 \mathrm{~m}$ at 1,7 and 14 days from birds placement, respectively, whereas Blue House II had $9.0 \times 40.0 \mathrm{~m}, 9.0 \times 80.0 \mathrm{~m}$ and $9.0 \times 120.0 \mathrm{~m}$ at 1, 7 days and 14 days from birds placement, respectively.

During the winter of 2009, the experiment was conducted at the broiler house named Dark House, located in Mombuca, in São Paulo state, Brazil, with average altitude of $550 \mathrm{~m}$ and Cwa climate presenting two seasons described according to Köppen's climate classification.

The aviary design was $18.0 \times 120.0 \times 3.0 \mathrm{~m}$ with eastwest orientation, and minimum ventilation was provided by exhaust fans and air exchanges through padcooling apertures that were turned off during the data collecting (Figure 1C). Brooding chamber dimension was $18.0 \times 50.0 \mathrm{~m}$, $18.0 \times 70.0 \mathrm{~m}$ and $18.0 \times 86.0 \mathrm{~m}$ at 1,7 and 14 days from birds placement, respectively.

The heating system was composed of wood burning furnaces placed in the middle of the brooding area. The furnaces utilized ducts for heat distribution where the hot air was then distributed throughout the house horizontally. Wood consumption was about 8.0 and $6.12 \mathrm{~m}^{3}$ during the brooding phase for Blue House I and Blue House II, respectively.

The broiler house had a false ceiling that went from one eave to the other. Ceiling was made of blue polyethylene material at $3.0 \mathrm{~m}$ of height. Sidewalls were composed of dwarf wall at $0.50 \mathrm{~m}$ high and mesh wire was covered by a double-layered blue polyethylene curtain and reflexive material onto the external surface of the curtains. The roof was covered by fiber-cement tiles.

The Dark House had a heat system composed of diesel fuel burning automatic heaters located in the middle of thebrooding chamber. The heater systems also utilized ducts for heat distribution, through which the hot air was then distributed all over the house. Fuel consumption was about 740 liters for the whole brooding phase. Ceiling was made of black reflective material on the inside surface and silvery reflective material on the outer surface (Foil ${ }^{\circledR}$ ) at $3.00 \mathrm{~m}$ high. Sidewalls were made of dwarf wall at 0.50 $\mathrm{m}$ high and mesh wire was covered by a double-layered black polyethylene curtain. Roof was covered by fibercement tiles.

Aviaries were equipped with nipple drinkers and supplemental feeders next to automatic feeders. Birds

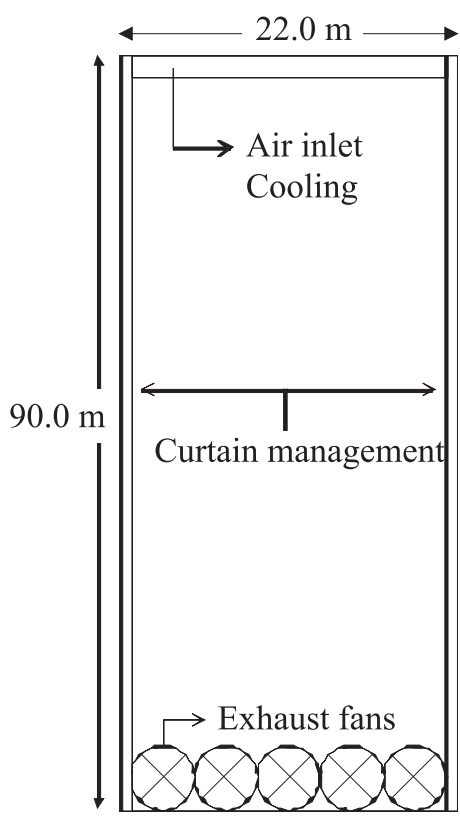

Ceiling height: $3.0 \mathrm{~m}$

(A)

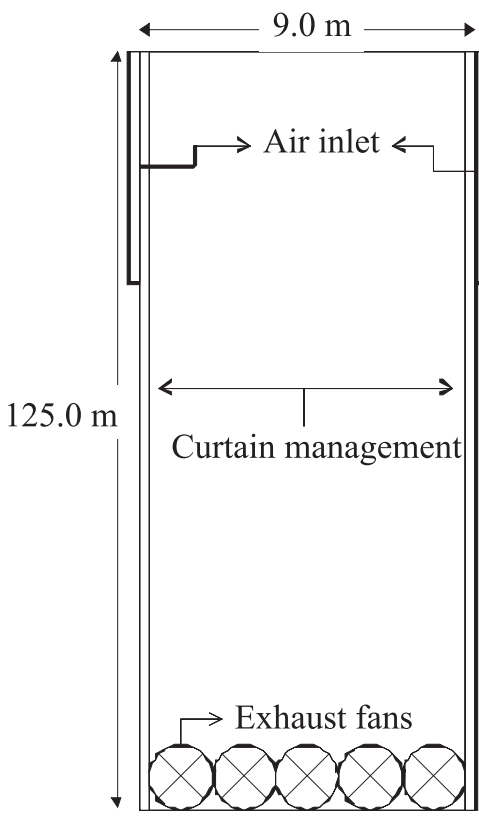

Ceiling height: $3.5 \mathrm{~m}$

(B)

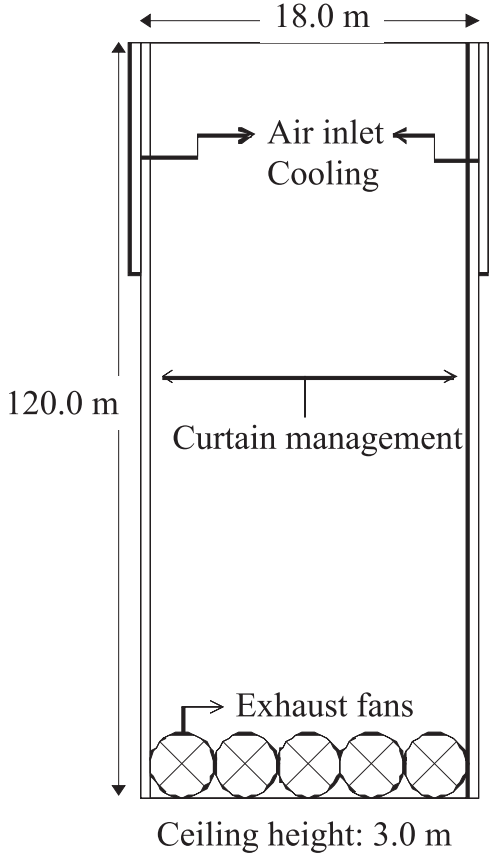

(C)

Figure 1 - Distribution of minimum ventilation systems in Blue House I (A), Blue House II (B) and Dark House (C). 
placement was 33660, 26000 and 32832 for birds placed in the Blue House I, Blue House II and Dark House respectively. All the housed birds were of Cobb-Vantress strain. The bedding material was a mix of coffee and rice hulls at second cycle in Blue House I and Blue House II, while the Dark House had wood shaving at the second cycle.

The climatic variables and gas concentration were metered onto 80 scanned points that were evenly measured throughout the brooding area, which had dimensions managed according to birds growing. In spite of this increase in the brooding area, the sampling of 80 points was maintained.

Dry bulb temperature (Tbs ${ }^{\circ} \mathrm{C}$ ) and relative humidity (UR \%) were measured through thermo-hydro-anemometer HTA 4200 model. Air velocity (Var m s${ }^{-1}$ ) was assessed using a hot-wire anemometer - VelociCalc ${ }^{\circledR} \mathrm{TSI}_{\mathrm{TM}}$ model. For $\mathrm{NH}_{3}$ and $\mathrm{CO}_{2}$ concentration readings, GasAlertMIcro 5 BW Technologies ${ }^{\circledR}$ was used. The data records were sampled at $9 \mathrm{~h}$ at the birds' height, i.e., $0.30 \mathrm{~m}$ in the height on the 80 equidistant points.

Climatic variables and gas concentration were evaluated by classical statistic analysis through mean and coefficient of variation (CV). The data normality test was performed through Kolmogorov-Smirnov test using the software SAS (Schlotzhaver \& Littell, 1997).

Spatial dependence was analyzed by semivariogram fitting (Vieira, 2000), based on the assumption of intrinsic stationary process, which is estimated by:

$\hat{\gamma}=\frac{1}{2 N(h)} \sum_{i=1}^{N(h)}\left[Z\left(x_{1}\right)-Z\left(x_{1}+h\right)\right]^{2}$

where $\mathrm{N}(\mathrm{h})$ denotes the set of pairs of observation $\mathrm{Z}$ (xi) and $\mathrm{Z}(\mathrm{xi}+\mathrm{h})$ separated by a lag distance $\mathrm{h}$. The semivariogram is represented by the relation $\hat{\gamma}(\mathrm{h})$ versus $h$. The semivariogram parameters of a theoretic model (nugget, $\mathrm{C}_{0}$; sill, $\mathrm{C}_{0}+\mathrm{C}_{1}$; and range, a) can be calculated from the adjusting of mathematic model from $\gamma(\mathrm{h})$.

Spatial dependence of attributes was analyzed according to Cambardella et al. (1994), who considers the strongly structured spatial dependence of semivariogram when presenting a nugget effect $<25 \%$ of sill, mild ranging from 25 to $75 \%$ and weak if $>75 \%$.

The semivariogram models were spherical, exponential and Gaussian, adjusted by software $\mathrm{GS}^{+}$(Robertson, 1998). Afterwards, these models were used in order to develop kriged maps (kriging). The semivariogram model was selected taking into account the greater correlation coefficient that was obtained by the cross-validation method. The maps of spatial distribution of variables were developed through the software Surfer (Golden Software, 1999).

\section{Results and Discussion}

According to the Kolmogorov-Smirnov, the variables that did not present normality were: dry bulb temperature and $\mathrm{NH}_{3}$ in Blue House I, air velocity and dry bulb temperature in Blue House II and dry bulb temperature, air velocity and $\mathrm{NH}_{3}$ in Dark House for 1-day; and air velocity and dry bulb temperature in Blue House I, air velocity and $\mathrm{NH}_{3}$ in Blue House II and dry bulb temperature, air velocity, $\mathrm{NH}_{3}$ and $\mathrm{CO}_{2}$ in Dark House for 7-day-old birds; and also, all variables in Blue House I, relative humidity, air velocity, and $\mathrm{CO}_{2}$ in Blue House II and dry bulb temperature, relative humidity, air velocity and $\mathrm{CO}_{2}$ in the Dark House for 14-dayold birds (Tables 1, 2 and 3). However, these variables had values near the mean and median, which allows assuming that the distributions are sufficiently symmetric.

According to Little \& Hills (1978), when the mean and median are similar, the data presents normal distribution. This may be an indication that the measures of central tendency are not dominated by outliers in the distribution (Cambardella et al., 1994).

According to Isaaks \& Srivastava (1989), more important than the normality of the data is the occurrence of proportional effect in which the mean and variance of the data are not constant values on the research field. This assumption could not be confirmed in this study, since the semivariograms showed well-defined levels (Figure 2). Faria et al. (2008)

Table 1 - Statistics of the variables of the thermal and aerial environment for treatment (T1) in Blue House I during minimum ventilation management for birds at 1,7 and 14 days of age

\begin{tabular}{ccccc}
\hline Variables & Average & Median & CV & d \\
\hline & \multicolumn{5}{c}{1 day old } \\
Tbs & 25.3 & 25.7 & 7 & 0.11 \\
$\mathrm{UR}$ & 71.9 & 72.3 & 6.4 & $0.07^{\mathrm{ns}}$ \\
$\mathrm{Var}$ & 0.1 & 0 & 280.7 & $0.06^{\mathrm{ns}}$ \\
$\mathrm{NH}_{3}$ & 57.8 & 58.5 & 12.3 & 0.14 \\
$\mathrm{CO}_{2}$ & 2938.1 & 2900 & 11.9 & $0.07^{\mathrm{ns}}$ \\
& & 7 days old & & \\
$\mathrm{Tbs}$ & 22.7 & 22.8 & 4.5 & 0.11 \\
$\mathrm{UR}$ & 41.7 & 41.8 & 8 & $0.07^{\mathrm{ns}}$ \\
$\mathrm{Var}$ & 0.2 & 0.2 & 69.9 & 0.19 \\
$\mathrm{NH}_{3}$ & 4.2 & 4 & 43.7 & $0.10^{\mathrm{ns}}$ \\
$\mathrm{CO}$ & & 700 & 42.1 & $0.05^{\mathrm{ns}}$ \\
& 638.1 & & & \\
$\mathrm{Tbs}$ & 21.6 & 21.9 & 11.8 & 0.19 \\
$\mathrm{UR}$ & 72.8 & 74.8 & 11.2 & 0.28 \\
Var & 0.3 & 0.2 & 68.1 & 0.06 \\
$\mathrm{NH}_{3}$ & 7.5 & 7 & 58.8 & 0.1 \\
$\mathrm{CO}_{2}$ & 607.3 & 537.5 & 70.9 & 0.12 \\
\hline
\end{tabular}

Tbs = dry bulb air temperature; UR = relative humidity; Var = air velocity; $\mathrm{NH}_{3}=$ ammonia concentration; $\mathrm{CO}_{2}=$ carbon dioxide concentration; $\mathrm{CV}=$ coefficient of variation; $\mathrm{d}=$ normality test; ${ }^{\mathrm{ns}}=$ non-significant at the Kolmogorov-Smirnov test. 
Table 2 - Statistics of the variables of thermal and aerial environment for treatment (T2) in Blue House II during minimum ventilation management for birds at 1,7 and 14 days of age

\begin{tabular}{|c|c|c|c|c|}
\hline Variables & Average & Median & $\mathrm{CV}$ & $\mathrm{d}$ \\
\hline \multicolumn{5}{|c|}{1 day old } \\
\hline Tbs & 25.6 & 25.9 & 4.8 & 0.17 \\
\hline UR & 50.8 & 50.2 & 11.6 & $0.08^{\mathrm{ns}}$ \\
\hline Var & 0.1 & 0 & 154.8 & 0.14 \\
\hline $\mathrm{NH}_{3}$ & 2.5 & 3 & 20.9 & $0.09^{\mathrm{ns}}$ \\
\hline $\mathrm{CO}_{2}$ & 710.6 & 700 & 34.3 & $0.05^{\mathrm{ns}}$ \\
\hline \multicolumn{5}{|c|}{7 days old } \\
\hline Tbs & 24.1 & 24 & 2.2 & $0.08^{\mathrm{ns}}$ \\
\hline UR & 31.7 & 31.8 & 4.8 & $0.06^{\mathrm{ns}}$ \\
\hline Var & 0.3 & 0.3 & 68.4 & 0.11 \\
\hline $\mathrm{NH}_{3}$ & 1.7 & 0 & 149.3 & 0.22 \\
\hline $\mathrm{CO}_{2}$ & 355.6 & 400 & 49.7 & $0.05^{\mathrm{ns}}$ \\
\hline \multicolumn{5}{|c|}{14 days old } \\
\hline Tbs & 22.2 & 22.4 & 5.1 & $0.09^{\mathrm{ns}}$ \\
\hline UR & 74 & 73.9 & 3 & 0.16 \\
\hline Var & 0.3 & 0.3 & 36 & 0.1 \\
\hline $\mathrm{NH}_{3}$ & 6.3 & 6.3 & 55.6 & $0.07^{\mathrm{ns}}$ \\
\hline $\mathrm{CO}_{2}$ & 487.8 & 412.5 & 55.6 & 0.1 \\
\hline
\end{tabular}

Tbs = dry bulb air temperature; UR = relative humidity; Var = air velocity; $\mathrm{NH}_{3}=$ ammonia concentration, $\mathrm{CO}_{2}=$ carbon dioxide concentration.

$\mathrm{CV}=$ coefficient of variation, $\mathrm{d}=$ normality test, ${ }^{\mathrm{ns}}=$ non-significant at the Kolmogorov-Smirnov test.

Table 3 - Statistics of the variables of the thermal and aerial environment for treatment (T3) in Dark House during minimum ventilation management for birds at 1,7 and 14 days of age

\begin{tabular}{|c|c|c|c|c|}
\hline Variables & Average & Median & $\mathrm{CV}$ & $\mathrm{d}$ \\
\hline \multicolumn{5}{|c|}{1 day old } \\
\hline Tbs & 19.7 & 19.9 & 3.1 & 0.16 \\
\hline UR & 83.1 & 83.6 & 3.4 & $0.09^{\mathrm{ns}}$ \\
\hline Var & 0.1 & 0.1 & 80.3 & 0.13 \\
\hline $\mathrm{NH}_{3}$ & 35.9 & 39 & 20.8 & 0.2 \\
\hline $\mathrm{CO}_{2}$ & 2958.6 & 3000 & 13.6 & $0.09^{\mathrm{ns}}$ \\
\hline \multicolumn{5}{|c|}{7 days old } \\
\hline Tbs & 22.7 & 22.9 & 2 & 0.16 \\
\hline UR & 88.8 & 88.6 & 2.7 & $0.08^{\mathrm{ns}}$ \\
\hline Var & 0.2 & 0.1 & 88.5 & 0.15 \\
\hline $\mathrm{NH}_{3}$ & 18.6 & 19 & 18.9 & 0.1 \\
\hline $\mathrm{CO}_{2}$ & 1619 & 1525 & 26.3 & 0.11 \\
\hline \multicolumn{5}{|c|}{14 days old } \\
\hline Tbs & 19.7 & 19.9 & 3.1 & 0.16 \\
\hline UR & 77.5 & 78.3 & 7.1 & 0.1 \\
\hline Var & 0.1 & 0.1 & 99.3 & 0.16 \\
\hline $\mathrm{NH}_{3}$ & 12.7 & 11.5 & 47.2 & $0.10^{\mathrm{ns}}$ \\
\hline $\mathrm{CO}_{2}$ & 361.1 & 400 & 42.2 & 0.11 \\
\hline
\end{tabular}

Tbs = dry bulb air temperature; $\mathrm{UR}=$ relative humidity; $\mathrm{Var}=$ air velocity; $\mathrm{NH}_{3}=$ ammonia concentration; $\mathrm{CO}_{2}=$ carbon dioxide concentration. $\mathrm{CV}=$ coefficient of variation; $\mathrm{d}=$ normality test; ${ }^{\mathrm{ns}}=$ non-significant at the Kolmogorov-Smirnov test.

studied the spatial variability of microclimate from a freestall dairy cattle facility that did not show normal distribution for the microclimatic attributes evaluated either.

The climatic variables and gas concentration evaluated from different environments showed spatial dependence, except for air velocity, which presented pure nugget effect in Blue House I and II during the first day of birds housing (Table 4). In this case, all the variability quantified by the semivariogram is attributed to the random effect, which cannot be related to spatial dependence (Vieira, 2000).

The $\mathrm{C}_{0} /\left(\mathrm{C}_{0}+\mathrm{C} 1\right)$ ratio showed that climatic variables presented strong and moderate levels of spatial dependence (Table 2). The greater the spatial dependence, the lower the contribution of the nugget effect on the variability of the data and the better the kriging.

The range shows that the limit distance of the collected sampling points are correlated, which contributes to the sample design and definition of where the climatic variables are sampled (McBratney \& Webster, 1983, Souza et al., 2006). The data showed values ranging from 6 to $99 \mathrm{~m}$. The Dark House had increased range of values in order $1<7<14$ days old.

Miles et al. (2008) reported the spatial dependence of the climatic attributes from a broiler house while investigating the temporal variability and spatial variability of nitrogen compounds and climatic variables with the use of geostatistical tools and kriged maps.

It was observed that the highest temperatures occurred near the heaters located in the middle of the brooding area, but the maximum temperature found in the aviary Dark House was $20.9^{\circ} \mathrm{C}$, indicating an inadequate management of the heating system during birds pre-placement (Figure 3). According to Medeiros et al. (2005), birds that undergo thermal comfort show better results in terms of feed conversion, weight gain and production efficiency, with the dry bulb temperature between 32 and $34{ }^{\circ} \mathrm{C}$ during the first weeks of the growing-out period. In addition, thermal comfort associated with animal welfare significantly improves the physiological conditions of the birds, which directly influences productivity (Lana et al., 2005; Welker et al., 2008).

On the seventh day of birds housing, none of the treatments was within the ideal temperature limit as reported by Nicholson et al. (2004), who recommended that limits be between 29 and $32{ }^{\circ} \mathrm{C}$ for broilers at this stage (Table 1 ). The same condition was observed at 14 days, thus, once more, none of the treatments had dry bulb temperature within the appropriate standards as recommended by Nicholson et al. (2004). These results can be explained by the influence of external conditions during the winter weather which, outdoor dry bulb temperature, was about $18^{\circ} \mathrm{C}$.

According to the classification of Warrick \& Nielsen (1980), the coefficient of variation for the temperature was low for Blue House I, Blue House II and Dark House during the different weeks of birds housing (Table 1). It is observed that the temperature values were adjusted to spherical, 
Blue House I - 1 day old
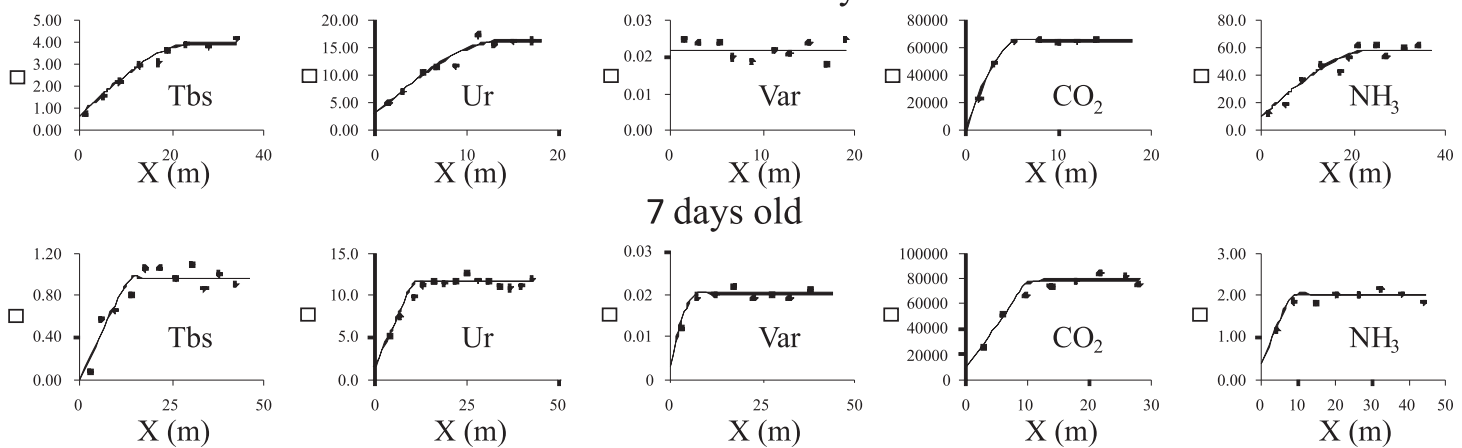

7 days old
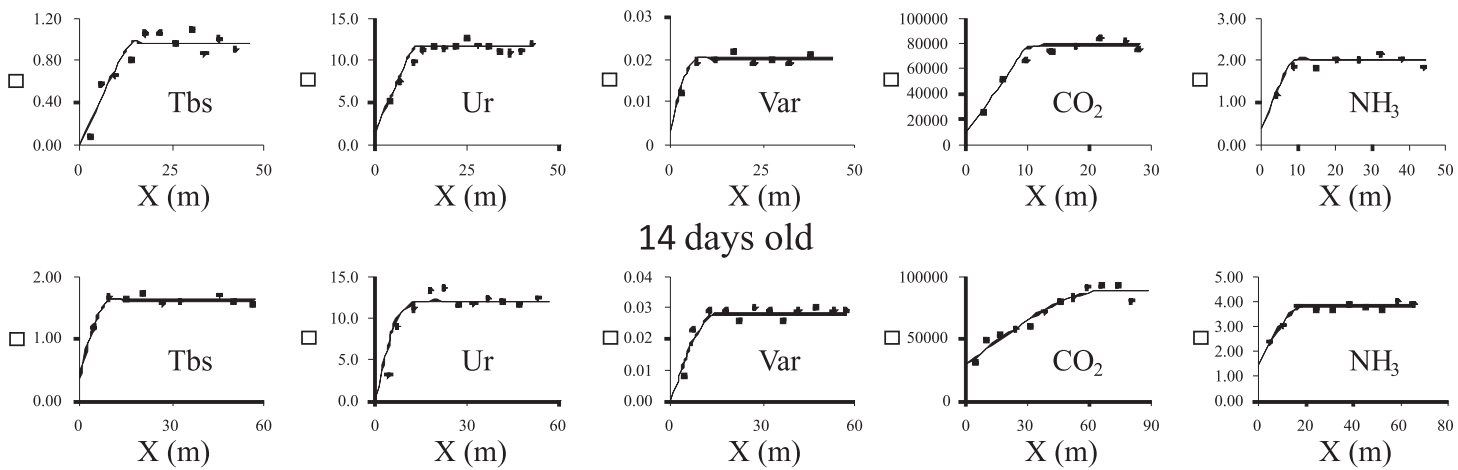

\section{4 days old}
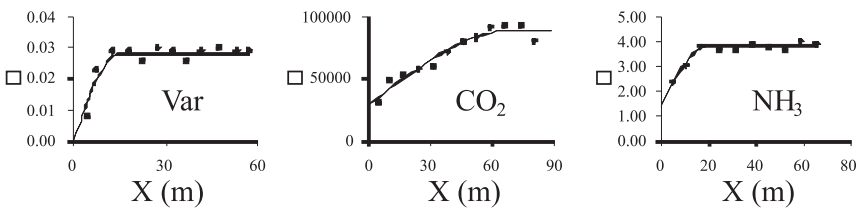

Blue House II - 1 day old
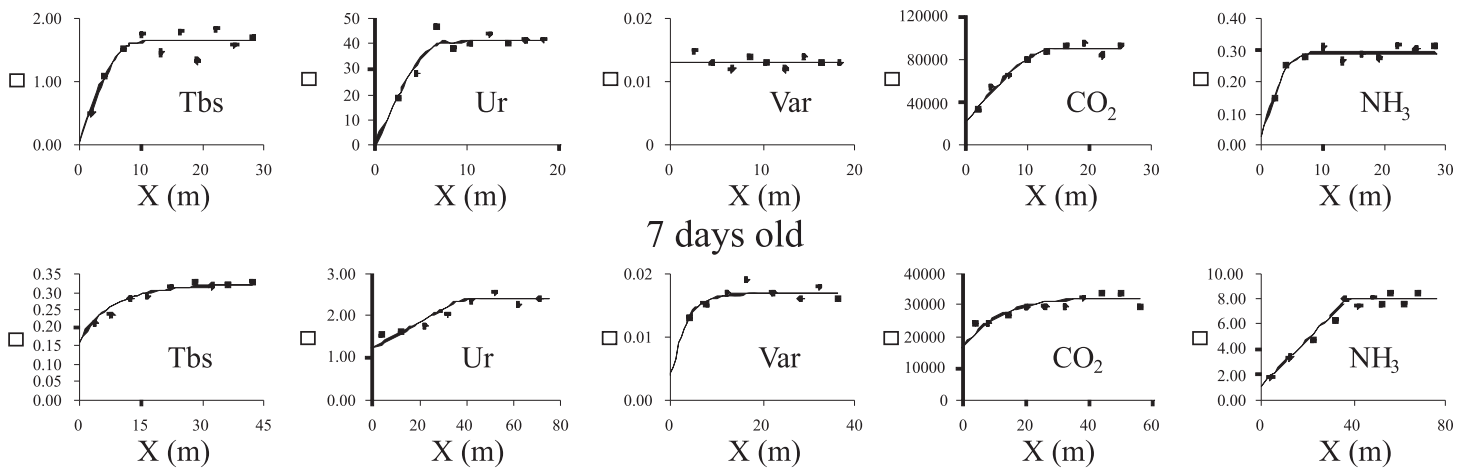

7 days old
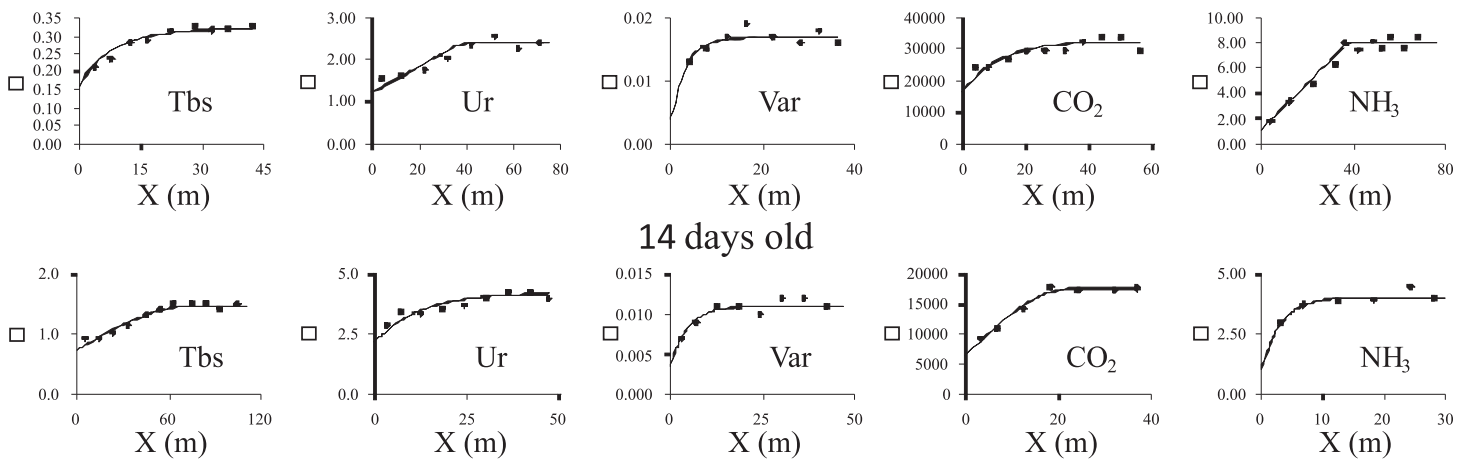

14 days old
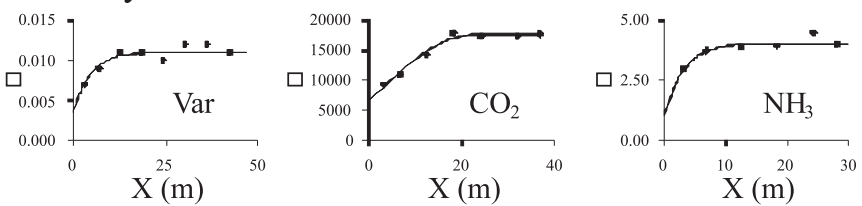

Dark House - 1 day old
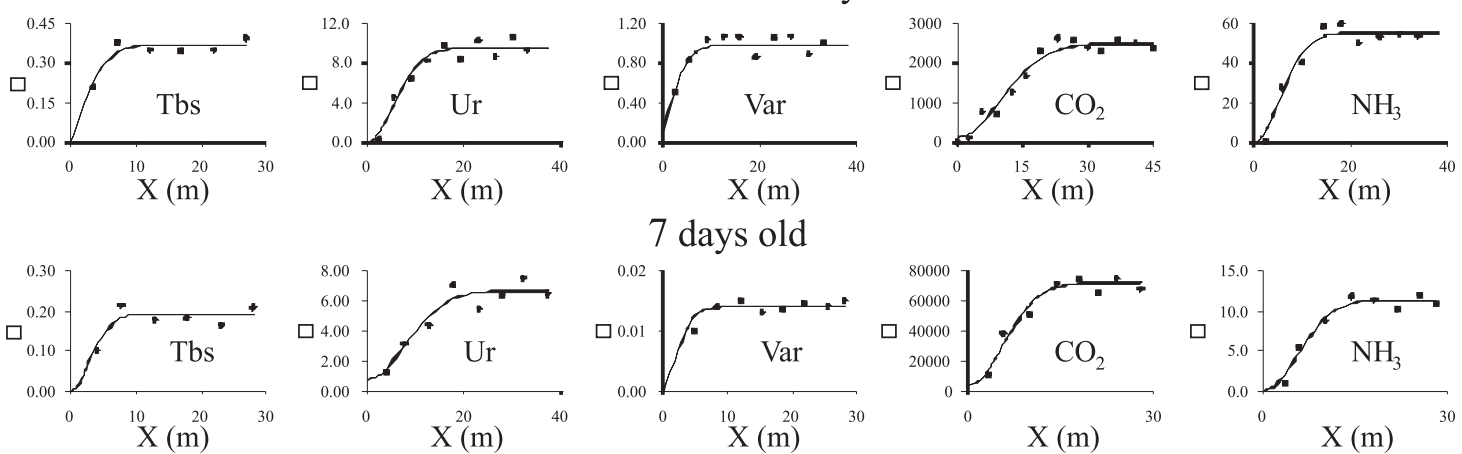

7 days old
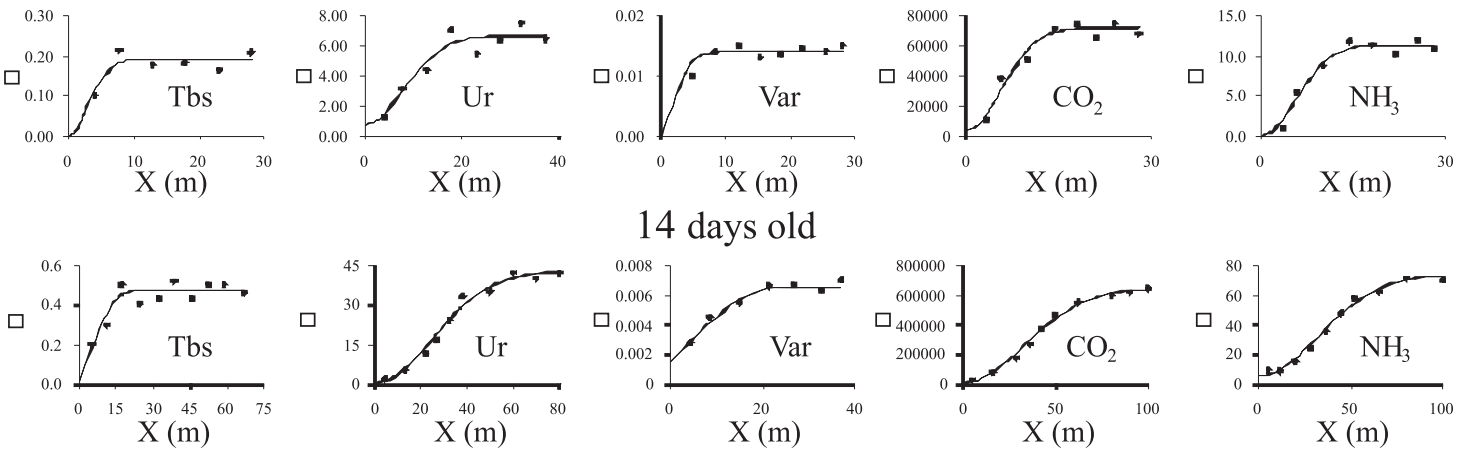

\section{4 days old}
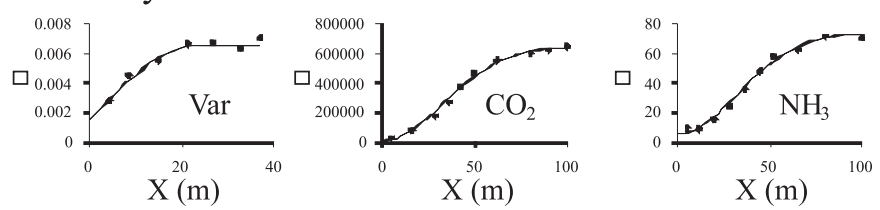

Figure 2 - Semivariograms of thermal and aerial environment of Blue House I (T1), Blue House II (T2) and Dark House (T3) during minimum ventilation management for birds at 1,7 and 14 days of age. 
Table 4 - Models and parameters of semivariograms for the variables of the thermal and aerial environment for Blue House I (T1), Blue House II (T2) and Dark Horse (T3) during minimum ventilation management for birds at 1, 7 and 14 days of age

\begin{tabular}{|c|c|c|c|c|c|c|c|c|c|c|c|c|}
\hline \multirow[t]{2}{*}{ Variable } & \multicolumn{4}{|c|}{1 day old } & \multicolumn{4}{|c|}{7 days old } & \multicolumn{4}{|c|}{14 days old } \\
\hline & Model & $\mathrm{A}$ & GDE & $\mathrm{R}^{2}$ & Model & A & GDE & $\mathrm{R}^{2}$ & Model & A & GDE & $\mathrm{R}^{2}$ \\
\hline & \multicolumn{12}{|c|}{ Blue House I } \\
\hline Tbs & ${ }^{6} \mathrm{ESF}$ & 25 & 15.19 & 0.96 & ESF & 20 & 0.10 & 0.72 & ESF & 10 & 22.36 & 0.72 \\
\hline UR & ESF & 14 & 17.07 & 0.94 & ESF & 20 & 0.10 & 0.96 & ESF & 11 & 0.08 & 0.69 \\
\hline Var & ${ }^{7} \mathrm{EPP}$ & - & - & - & ESF & 22 & 40.00 & 0.91 & ESF & 15 & 0.00 & 0.90 \\
\hline $\mathrm{NH}_{3}$ & ESF & 24 & 16.49 & 0.91 & ESF & 12 & 19.19 & 0.87 & ESF & 19 & 36.75 & 0.95 \\
\hline $\mathrm{CO}_{2}$ & ESF & 6 & 0.15 & 0.99 & ESF & 16 & 10.41 & 0.97 & ESF & 70 & 32.15 & 0.95 \\
\hline \multicolumn{13}{|c|}{ Blue House II } \\
\hline Tbs & ESF & 9 & 3.68 & 0.85 & EXP & 25 & 50.00 & 0.97 & GAU & 90 & 49.97 & 0.60 \\
\hline $\mathrm{Ur}$ & ESF & 8 & 0.24 & 0.85 & ESF & 58 & 50.00 & 0.89 & ESF & 9 & 10.49 & 0.44 \\
\hline Var & EP P & - & - & - & EXP & 10 & 23.53 & 0.64 & EXP & 15 & 18.92 & 0.31 \\
\hline $\mathrm{NH}_{3}$ & ESF & 7 & 10.34 & 0.89 & ESF & 56 & 13.38 & 0.88 & GAU & 99 & 20.57 & 0.81 \\
\hline $\mathrm{CO}_{2}$ & ESF & 15 & 23.99 & 0.96 & EXP & 35 & 49.98 & 0.76 & GAU & 10 & 4.84 & 0.95 \\
\hline \multicolumn{13}{|c|}{ Dark House } \\
\hline Tbs & ESF & 8 & 0.03 & 0.81 & GAU & 7 & 0.00 & 0.74 & ESF & 21 & 4.26 & 0.82 \\
\hline $\mathrm{Ur}$ & GAU & 14 & 0.11 & 0.97 & GAU & 20 & 10.54 & 0.99 & GAU & 58 & 0.74 & 0.98 \\
\hline Var & GAU & 7 & 7.14 & 0.99 & ESF & 6 & 0.07 & 0.78 & ESF & 23 & 28.57 & 0.98 \\
\hline $\mathrm{NH}_{3}$ & GAU & 13 & 0.18 & 0.92 & GAU & 14 & 0.09 & 0.97 & GAU & 80 & 8.33 & 0.90 \\
\hline $\mathrm{CO}_{2}$ & GAU & 25 & 5.64 & 0.98 & GAU & 33 & 6.83 & 0.97 & GAU & 81 & 0.22 & 0.90 \\
\hline
\end{tabular}

Tbs age = dry bulb air temperature; UR = relative humidity; Var = air velocity; $\mathrm{NH}^{3}=$ ammonia concentration; $\mathrm{CO}_{2}=$ carbon dioxide concentration; $\mathrm{ESF}=$ spherical; $\mathrm{EPP}=$ pure nugget effect; GAU = Gaussian; $\mathrm{EXP}=$ exponential; $\mathrm{A}=$ range; GDE = degree of spatial dependence; $\mathrm{R}^{2}=$ squared error.

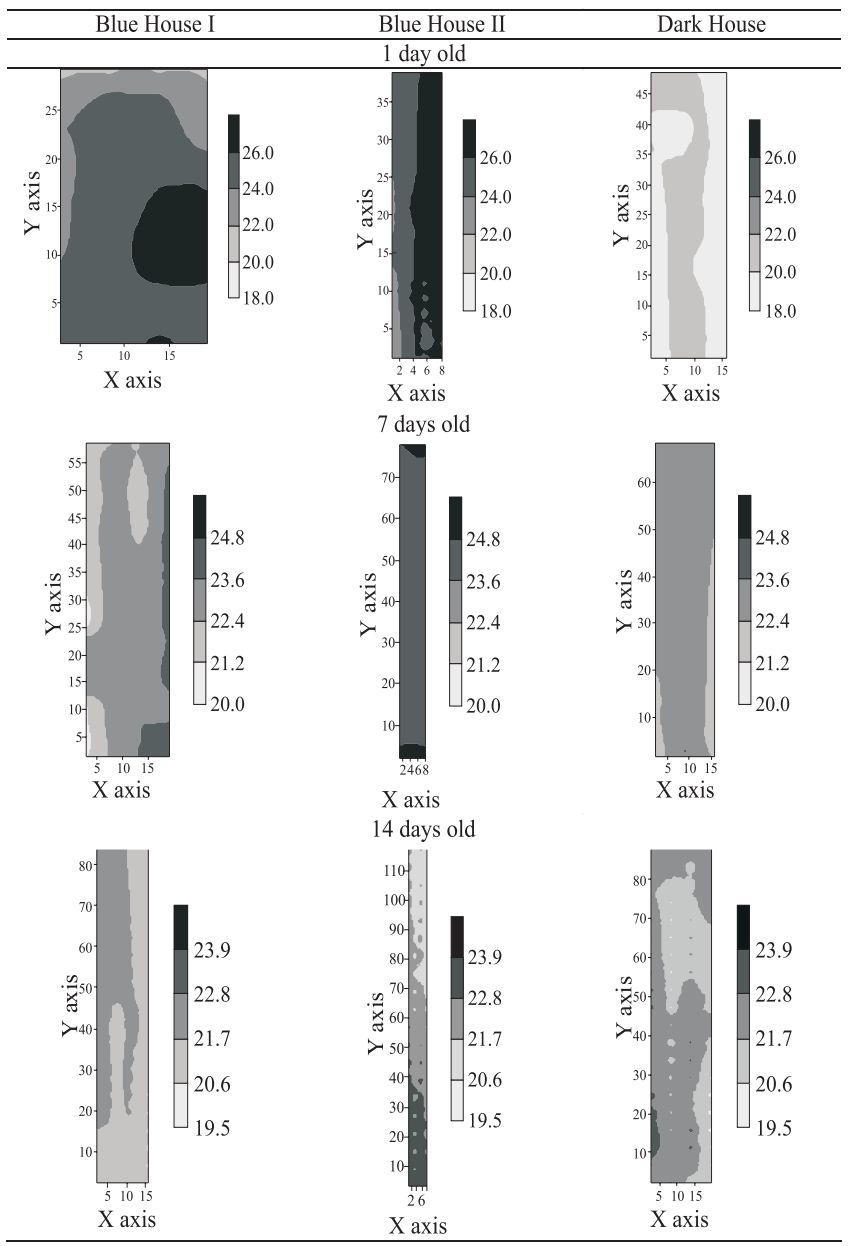

Figure 3 - Kriged maps of dry bulb temperature - Tbs $\left({ }^{\circ} \mathrm{C}\right)$ in Blue House I, II and Dark House for birds at 1, 7 and 14 days of age. exponential and Gaussian models for the three treatments and three weeks that were evaluated (Table 2). These models are defined as non-stationary (Isaaks \& Srivastava, 1989), since they presented sill, i.e., from a lag distance between samples there is no more spatial dependence.

The relative humidity evaluated in Blue House I and Blue House II during the 7 days of birds housing was within the thermal comfort levels of 35 and 60\% (Elwing \& Svensson, 1996). The same condition was observed in Blue House II for 14-day old birds. The distribution of this variable was homogeneous on the three treatments. In addition, the spherical semivariogram model was fitted to the Blue House I and Blue House II, while the Gaussian model was fitted to the Dark House with a strong degree of dependence for sheds Dark House and Blue House II, and moderate one to shed Blue House I (Table 2). The degree of spatial dependence was weak for Blue House I and strong for Blue House II and Dark House (Table 2).

The high value of this attribute for all treatments may be related to the high outside relative humidity recorded by the weather station, whose average value was $90 \%$, which shows the of lack of advantage to the grower to promote the air renewal in order to solve this problem, instead of managing the heating system.

Relative humidity was higher in all treatments than recommended by the literature (Figure 4 ), greater than $60 \%$ (Elwing \& Svensson, 1996). The highest relative humidity in Blue House I can be explained by its width of $22.0 \mathrm{~m}$, which 
made the air exchange inefficient due to the larger volume of air presented in this aviary. In regard to the Dark House, adding to the fact that it was completely closed, the excessive humidity promoted the built up of moisture that increased the average value of this attribute during the winter, which agrees with the results obtained by Miragliotta et al. (2006).

The lack of uniformity of relative humidity was also reported by Faria et al. (2008), through kriged maps where the spatial variability of the microclimate of a free-stall for dairy cattle housing was plotted.

According to Vanni (1998), a coefficient of variation greater than $35 \%$ shows that the dataset is heterogeneous and the mean is not a strong parameter. Considering this assumption, the microclimatic attribute, such as wind speed presented a range of heterogeneous data turning the mean into not significant. However, the attributes of air temperature and relative humidity presented a homogeneous variation because the coefficient of variation is low $(<12 \%)$, according to the criterion established by Warrick \& Nielsen(1980).

The air velocity showed pure nugget effect in Blue House I and II at the 1-day old birds housing, which pointed

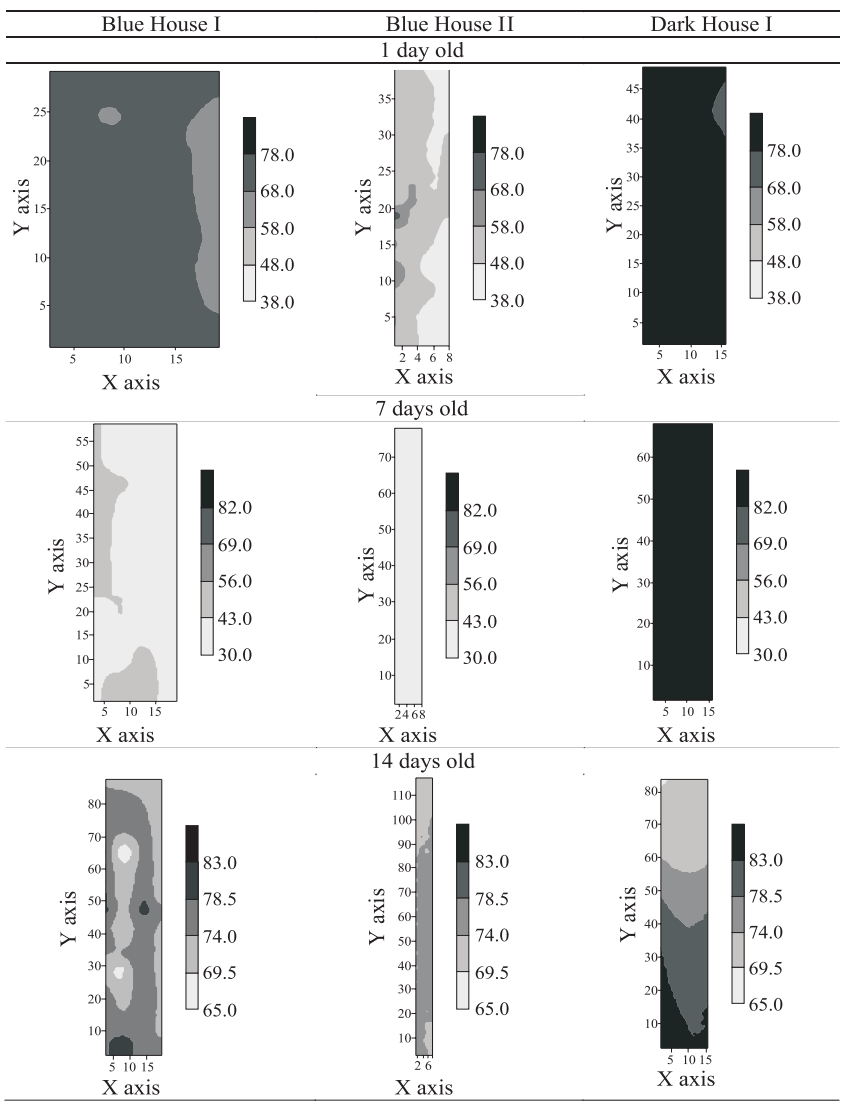

Figure 4 - Kriged maps for relative humidity - UR (\%) in Blue House I, II and Dark House for birds at 1, 7 and 14 days of age. out the lack of spatial dependence of dataset (Table 2). The nugget effect reflects the variability that was not explained by the sampling data distance, such as local variations, errors in analysis, in sampling and other errors. The pure nugget effect can be also explained by high variability within the aviary due to management of curtains in Blue House I and II, which were greatly influenced by the outside environment. Dark House had the spherical, exponential and Gaussian models fitted to the semivariograms of this variable, air velocity.

The air velocity (Figure 5) showed an ideal average value, i.e., below $0.5 \mathrm{~m} \mathrm{~s}^{-1}$, as recommended by Simmons et al. (2003). The air velocity distribution was random, as reported by Faria et al. (2008) which pointed out an improper uniformity of air exchange. This high spatial variability can be confirmed by its high coefficient of variation and it can be explained due to the fact that the wind is characterized by changing its magnitude and direction constantly with variations of up to $100 \%$ of the average magnitude within a five-minute interval (Faria et al., 2008).

The air renewal influences the birds behavior positively through the maximum wind speed of $0.59 \mathrm{~m} \mathrm{~s}^{-1}$ which may

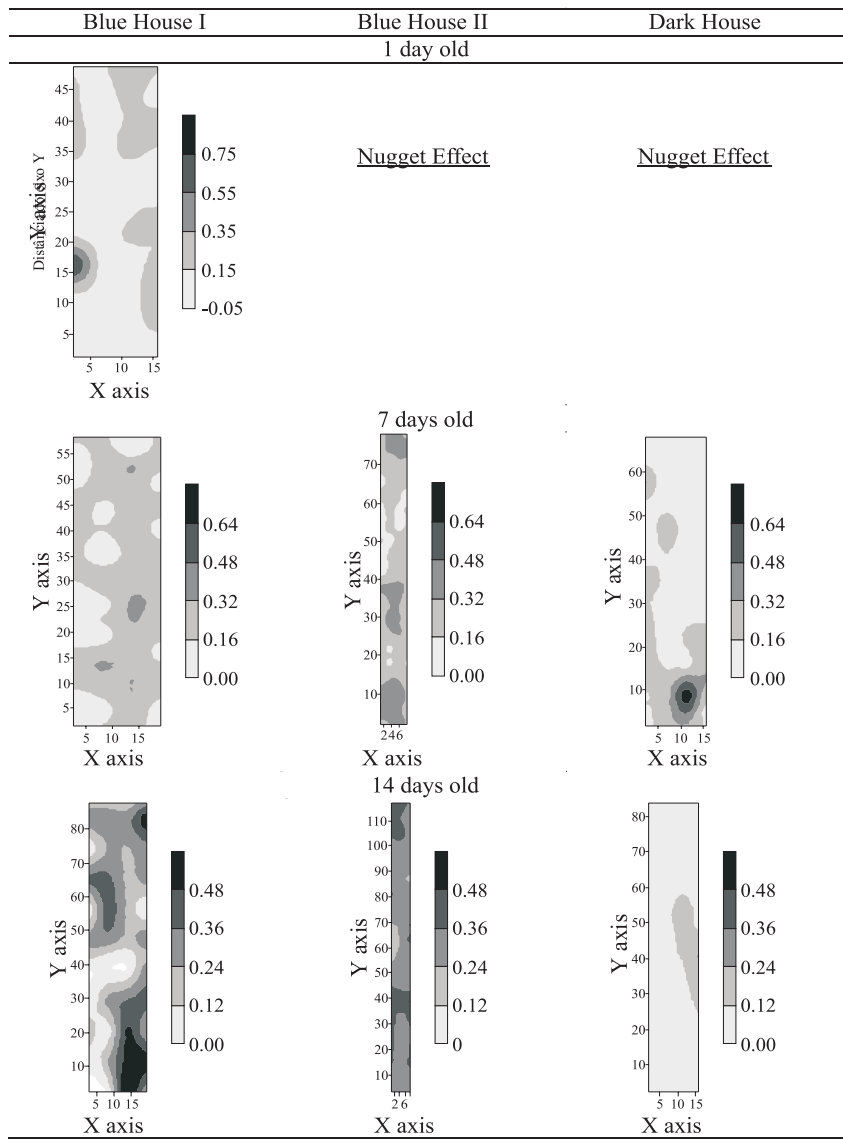

Figure 5 - Kriged maps for air velocity - Var $\left(\mathrm{m} \mathrm{s}^{-1}\right)$ in Blue House I, II and Dark House for birds at 1, 7 and 14 days of age. 
provide the maintenance of $\mathrm{NH}_{3}$ and $\mathrm{CO}_{2}$ concentrations to lower limits than those recommended by Manning et al. (2007). Through Figures 6 and 7 it can be noticed that although the gas concentration was high in some areas, these values only occurred in small areas near the exhaust fans in Blue House I.

The ammonia concentration was 57.8 and 35.93 ppm in Dark House and Blue House I, respectively (Figure 6). These values were above the recommended limit of $20 \mathrm{ppm}$, which can be harmful to the birds' welfare (Manning et al., 2007). This variable distribution was homogeneous in Blue House I, with an average variability for the other houses. It is assumed that the lower concentrations of ammonia found in Blue House II were due to lower volume of air being renewed by the management of minimum ventilation system, curtains and exhaust fans efficiency.

Coefficients of variation (CV) are dimensionless, and high values of CV can be considered as first indications of dataset heterogeneity (Table 1). When criterion of classification established by Warrick \& Nielsen (1980) is taken into account, we can see that the attribute $\mathrm{NH}_{3}$ showed an average variability in all houses evaluated

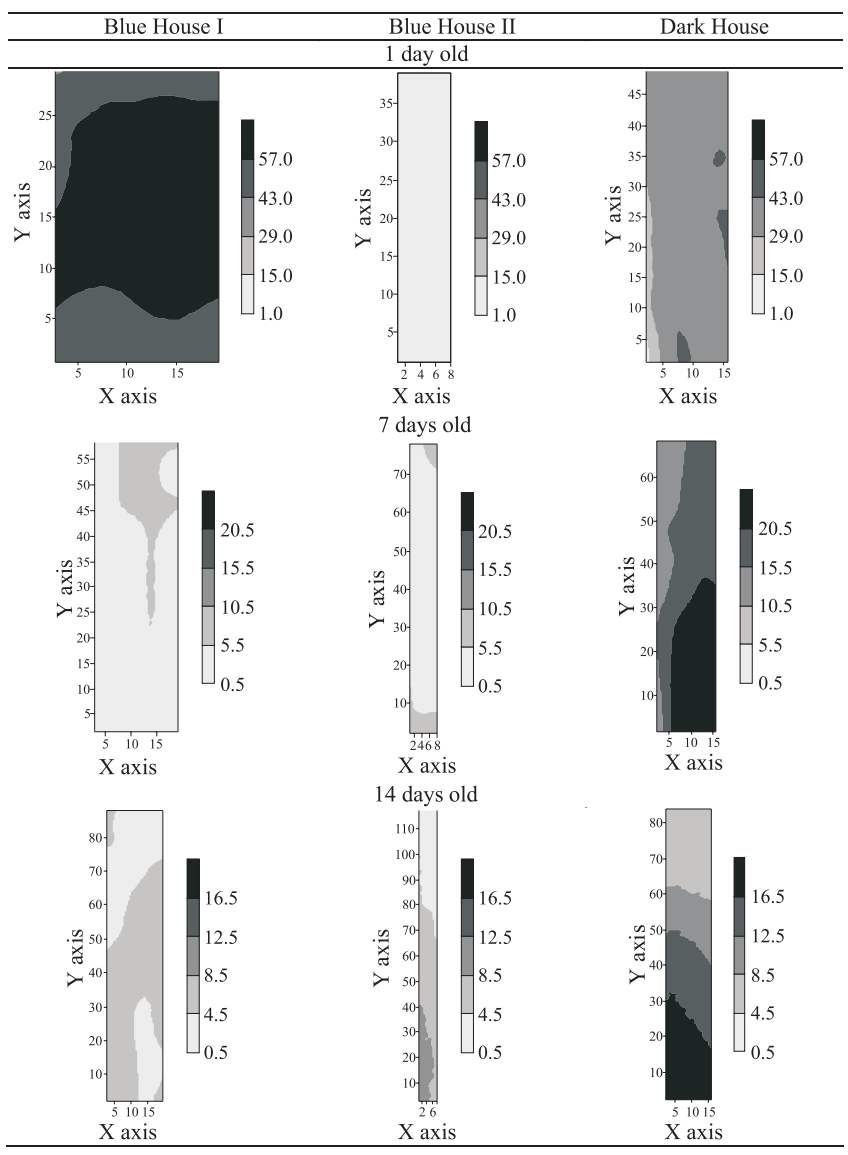

Figure 6 - Kriged maps for $\mathrm{NH}_{3}$ concentration (ppm) in Blue House I, II and Dark House for birds at 1, 7 and 14 days of age.
$(12 \%<\mathrm{CV}<24 \%)$. The ammonia concentration data were fitted to the spherical model for Blue House I and II, and the Gaussian model was fitted to the Dark House (Table 2).

Gas concentration is greater on the left side of the Blue House II (Figure 6), which was probably influenced by the management of curtains on the right side. Asimilar variation in the Dark House can be also observed, with higher gas concentration next to the exhaust fans and lower concentration on the opposite side, because of the air inlets.

The carbon dioxide concentration presented higher levels in Blue House I and Dark House. According to the criterion of Warrick \& Nielsen (1980), the coefficient of variation for the $\mathrm{CO}_{2}$ concentration ranged from medium to high (Table 1). The semivariograms were fitted to a spherical model for Blue House I and Gaussian model for Dark House (Table 2). The concentration of this gas was lower in the Blue House II, which can be explained by the same reasons pointed out for ammonia gas concentration.

Distributions of variables, ammonia (Figure 6) and carbon dioxide concentration (Figure 7) showed higher

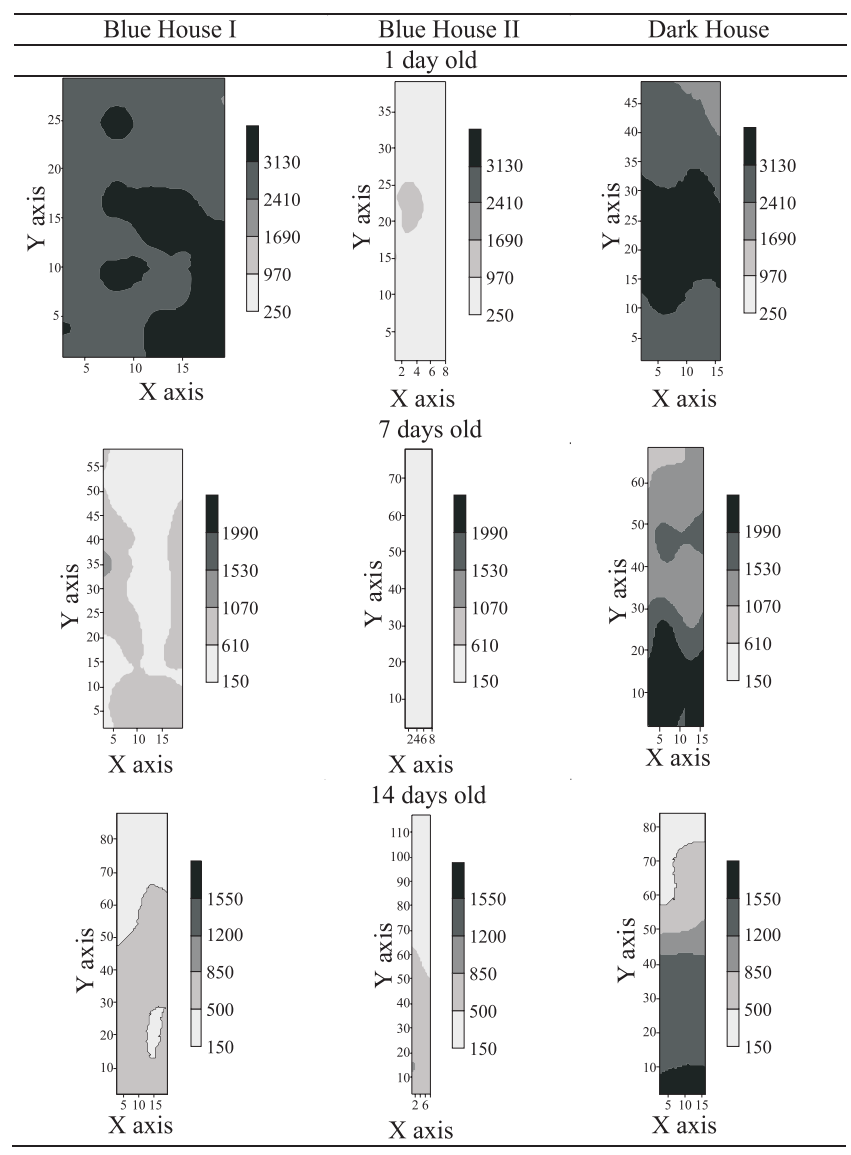

Figure 7 - Kriged maps for $\mathrm{CO}_{2}$ concentration (ppm) in Blue House I, II and Dark House for birds at 1, 7 and 14 days of age. 
values near to the exhaust fans area and heterogeneous distribution. Dark house presented the highest values. Similar results were obtained by Miragliotta et al. (2006), analyzing farms with negative pressure with birds close to the market weight. The ammonia concentration showed a similar variation in Blue House I and II, which differed significantly from Dark House $(\mathrm{P}<0.000)$, whereas carbon dioxide only showed a significant difference between the Dark House and Blue House I $(\mathrm{P}<0.000)$.

\section{Conclusions}

There is also need for improvement related to the volume of air to be heated and renewed with fresh air, to achieve the ideal temperature and air quality to improve birds health and meat production.

\section{References}

CORDEIRO, M.B.; TINOCO, I.F.F.; SILVA, J.N. et al. Conforto térmico e desempenho de pintos de corte submetidos a diferentes sistemas de aquecimento no período de inverno. Revista Brasileira de Zootecnia, v.39, n.1, p.217-224, 2010.

CAMBARDELLA, C.A.; MOORMAN, T.B.; NOVAK, J.M. et al. Field scale variability of soil properties in Central Iowa soils. Soil Science Society of America Journal, v.58, n.5, p.1501-1511, 1994.

ELWINGER, K.; SVENSSON, L. Effect of dietary protein content, litter and drinker types on ammonia emission from broiler house. Journal of Agricultural Engineering Research, v.64, p.197-208, 1996.

FARIA, F.F.; MOURA, D.J.; SOUZA, Z.M. et al. Variabilidade espacial do microclima de um galpão utilizado para confinamento de bovinos de leite. Ciência Rural, v.38, n.9, p.2498-2505, 2008.

GOLDEN SOFTWARE INC. Surfer for windows: realese 7.0, contouring and 3D surface mapping for scientist's engineers user's guide. New York: Golden software, 1999. 619p.

ISAAKS, E.H.; SRIVASTAVA, R.M. An introduction to applied geoestatistics. New York: Oxford University Press, 1989. $561 \mathrm{p}$.

LANA, S.R.V.; OLIVEIRA, F.R.M.; DONZELE, J.L. et al. Níveis de lisina digestível em rações para frangos de corte de 22 a 42 dias de idade, mantidos em ambiente de termoneutralidade. Revista Brasileira de Zootecnia, v.34, n.5, p.1624-1632, 2005. Available at: <http://www.revistasbz.org.br/scripts/revista/ sbz1/Artigos/4604.PDF>. Accessed on: Apr. 13, 2010.

LiTTLE, T.M.; HILLS, F.J. Agricultural experimentation: design and analysis. New York: John Wiley \& Sons, 1978. 368p.
McBRATNEY, A.B.; WEBSTER, R. How many observations are needed for regional estimation of soil properties? Soil Science, v.135, n.3, p.177-183, 1983.

MAXWELL, M.H.; ROBERTSON, G.W. UK survey of brolier ascites and sudden death syndromes in 1993. British Poultry Science, v.39, p.203-215, 1998.

MANNING, L.; CHADD, S.A.; BAINES, R.N. Key health and welfare indicators for broiler production. Poultry Science, v.63, p.63-68, 2007.

MEDEIROS, M.M.; BAETA, F.C.; OLIVEIRA, R.F.M. et al. Efeitos da temperatura, umidade relativa e velocidade do ar em frangos de corte. Engenharia na Agricultura, v.13, n.4, p.277-286, 2005.

MILES, D.M.; BRANTON, S.L.; LOTT, B.D. Atmospheric ammonia is detrimental to the performance of modern commercial broilers. Poultry Science, v.83, n.10, p.1650-1654, 2004.

MILES, D.M.; ROWE, D.E.; OWENS, P.R. Winter broiler litter gases and nitrogen compounds: temporal and spatial trends. Atmospheric environment, v.42, n.14, p.3351-3363, 2008.

MILES, J.W.; CARDONA, C.; SOTELO, G. Recurrent selection in a synthetic brachiaria grass population improves resistance to three spittlebug species. Crop Science, v.46, p.1088-1093, 2006.

MIRAGLIOTTA, M.Y.; NAAS, I.A.; MANZIONE, R.L. et al. Spatial analysis of stress conditions inside broiler house under tunnel ventilation. Scientia Agrícola, v.63, p.426-432, 2006.

NICHOLSON, F.A.; CHAMBERS, B.J.; WALKER, A.W. Ammonia emissions from broiler litter and laying hen manure management systems. Biosystems Engineering, v.89, n.2, p.175-185, 2004

REDWINE, J.S.; LACEY, R.E.; MUKHTAR, S. et al. Concentration and emissions of ammonia and particulate matter in tunnelventilated broiler houses under summer conditions in Texas. Transactions of ASAE, v.45, n.4, p.1101-1109, 2002.

ROBERTSON, G.P. GS+: geostatistics for the environmental sciences (version 5.1 for windows). Plainwell: Gamma Design Soffware, 1998. 152p.

SCHLOTZHAVER, S.D.; LITTELL, R.C. SAS: system for elementary statistical analysis. 2.ed. Cary, 1997. 905p.

SIMMONS, J.D.; LOTT, B.D.; MILES, D.M. The effects of highair velocity on broiler performance. Poultry Science, v.82, n.2, 232-234, 2003.

SOUZA, Z.M.; MARQUES JÚNIOR, J.; PEREIRA, G.T. et al. Otimização amostral de atributos de latossolos considerando aspectos solo-relevo. Ciência Rural, v.36, n.3, p.829-836, 2006.

VANNI, S.M. Modelos de regressão: estatística aplicada. São Paulo: Legmar Informática \& Editora, 1998. 177p.

VIEIRA, S.R. Geoestatística em estudos de variabilidade espacial do solo. In: NOVAIS, R.F.; ALVARES, V.H.; SCHAEFER, C.E.G.R (Eds.). Tópicos em ciência do solo. Viçosa, MG: Sociedade Brasileira de Ciência do Solo, 2000. v.1, p.1-53.

WARRICK, A.W.; NIELSEN, D.R. Spatial variability of soil physical properties in the field. In: HILLEL, D. (Ed.). Applications of soil physics. New York: Academic, 1980. p.319-344.

WELKER, J.S.; ROSA, A.P.; MOURA, D.J. et al.Temperatura corporal de frangos de corte em diferentes sistemas de climatização. Revista Brasileira de Zootecnia, v.37, n.8, p.1463-1467, 2008. Available at: <http://www.revistasbz.org.br/scripts/revista/ sbz1/Artigos/6510.PDF>. Accessed on: Apr. 13, 2010. 